\title{
ANTUNES, António Lobo. Boa tarde às coisas aqui em baixo. Lisboa: Dom Quixote, 2002
}

Cid Ottoni Bylaardt Universidade Federal de Minas Gerais

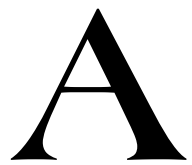

ntónio Lobo Antunes, em seu último livro, Boa tarde às coisas aqui em baixo, sugere em epígrafe uma justificativa para o título do romance:

Larbaud conservó enteras su lucidez y su memoria, pero cayó en una confusión total del lenguage, carente de organización sintáctica, reducida a sustantivos o infinitivos aislados, reducido a un mutismo inquietante que un día, de pronto, ante la sorpresa de los amigos que habían ido a visitarle, rompió com esta frase:

- Bon soir les choses d'ici bas.

Buenas tardes a las cosas de aquí abajo? Una frase intraducible.

Enrique Vila-Matas, Bartleby y Compañia

A epígrafe faz referência ao escritor francês Valéry Larbaud, que passou os últimos vinte anos de sua vida em uma cadeira de rodas, a rirse da vaidade do mundo, deste nosso mundo "de aquí abajo". E é a partir da vanidad e da inutilidade das coisas e das pessoas é que Lobo Antunes constrói essa história que se repete por 573 páginas, num eterno começo de uma mesma coisa que nunca é igual a ela mesma, de ações que parecem coincidir em sua mediocridade e inutilidade.

A arquitetura da obra é bastante clássica, e se anuncia após o título: "romance em três livros com prólogo e epílogo", contendo cada livro dez capítulos de tamanhos equivalentes. O que pode haver de clássico nessa obra pára aí.

A ação se passa na Angola pós-descolonização. Agentes portugueses são enviados à África pelo "Serviço", um órgão militar português não-formalizado, para recuperar diamantes contraban- 
deados e caçar contrabandistas. Assim se sucedem os personagens, matando-se e tentando recuperar coisas irrecuperáveis.

O prólogo mostra um desses agentes acompanhando uma africana branca (ou mestiça?) criada no meio das pretas, a tentar reconstituir sua trajetória de sobrinha de um dos contrabandistas mais procurados. O interesse do agente na sobrinha supõe-se que esteja na possibilidade de ela indicar o paradeiro das pedras. O texto do prólogo faz referências variadas a relatórios, "documentos classificados", mapas e coordenadas, apêndices, glossários e todo tipo de texto que um documento oficial deve conter.

Essa escrita oficial que aparece no prólogo já é em si um texto condenado, porque sua divulgação pode comprometer o Serviço, que executa operações ilegais. Essa é, portanto, uma escrita inútil e perigosa.

O primeiro livro contém os relatos alternados do Seabra, um dos "agentes secretos", e a Marina, a sobrinha do mencionado contrabandista. Os depoimentos do Seabra contêm referências ao caráter documental do texto, e os da Marina sugerem um relato de alguém que é interrogado, mas eles não escapam de imprimir considerações extremamente subjetivas ao "documento".
Em meio ao intimismo de seu relatório, o Seabra vislumbra a presença de um certo Miguéis, que viria substituí-lo após eliminá-lo e destruir os documentos. Após esse Miguéis, haveria um Borges, e assim por diante. Cada um desses zelosos agentes é identificado a um touro, "igualmente obrigado a avançar, mugindo de pavor, por trapos coloridos de reproduções de telefonemas, diagramas, formas geométricas" (p. 36). Assim, um touro atrás do outro é enviado à arena, na tentativa de mostrar sua performance no espetáculo e em seguida oferecer-se à morte que limpa o terreno para a entrada de outro animal.

O segundo livro repisa o primeiro com o agente Miguéis, que elimina o Seabra. Nessa parte, a mulher do segundo touro, o que repete importantes conselhos aos mais novos, do tipo "se não educam as vossas esposas desde o princípio estamos mal”, cai nos braços do tenente-coronel que enviou o marido a Angola. A voz predominante no segundo livro é a do Miguéis, que cede a narrativa à própria esposa nos capítulos seis e nove.

No terceiro livro, a história da perseguição se repete: há um grupo de homens que anda na mata, possivelmente carregando diamantes, perseguidos por 
militares que tentam resgatar as jóias e, naturalmente, matá-los. Cada um dos capítulos ímpares é narrado por um dos fugitivos, e os pares têm como voz o major Morais, mais um dos "touros" que seguem seu destino.

Todos comparecem a contar histórias, a escrever ou a simular escritas, cartas, relatórios, depoimentos, num total de onze vozes emergindo aqui e ali, mais o autor, que tenta se manter como comandante do relato mas perde o controle, seja porque os personagens se constroem a si mesmos, seja porque o "dono" do romance não é ouvido e as histórias se sucedem apesar da presença dele, que em certo momento emerge da narrativa, em meio a várias vozes, e declara ter sido apoderado pela escrita:

(quem me conta esta história, quem narra isto por mim?

uma traineira não, nem pássaros, nem mulatas que te melhorem o capítulo António, acordas com o romance, adormeces com o romance e a Marina que pensavas haver criado e se criou a si mesma a insistir dentro de ti

- Sou mestiça

esta narrativa que mais do que as outras se tornou uma doença que te gasta e de que não sabes curar-te, pode ser

vá lá, experimenta

que uma suspeita de vento ou um soluço de pavões

não existiam pavões, diante de tanta fome, como existiriam pavões?) (p. 121)

Esse é o mundo de baixo a que se dá boa tarde, o mundo que para um é sinônimo de inferno, para outro é um mundo permanentemente amarelo, em que os homens são touros, cães, animais que cumprem um destino. Acima de tudo, cumprem uma escrita, um jorro incessante de palavras inúteis, que não resolvem nada, não apaziguam, não exemplam.

E para fechar esse amontoado de textos, o epílogo constitui-se numa redação infantil, de uma garotinha portuguesa que passou as férias grandes em Luanda com o pai e a mãe. A cena descrita pela menina desenvolve-se num iate, em que aparecem, além do pai e da mãe dela, um casal de estrangeiros e um angolano negro, chamado de "caro almirante", acompanhado de dois filhos menores. Todos se divertem, e o tempo é de paz e de abundância (para eles).

Apesar de mostrar uma estrutura aparentemente usual, o emaranhado de vozes que 
emergem na narrativa criam texto não apazigua o desejo de fragmentos espaciais e temporais compreendê-lo como verdade do conduzem a uma leitura vertiginosa mundo, remetendo-o a uma e aparentemente desconexa. O incômoda ambigüidade que se leitor é então solicitado a recompor esconde atrás das palavras que os blocos de textos para conferir um certo sentido a esse relato instigante e original.

Ao final, após a reorganização dos elementos narrativos, o leitor se pergunta para que ela serviu, e descobre que o sentido do todo mundo usa. O sentido então circula errante por toda a escrita sem chegar a lugar nenhum, permanecendo nessa existência de baixo de forma tão esclarecedora quanto a frase que dá título ao livro. Sem solução, sem conclusão. 